\title{
LONG-TERM WEATHERING EFFECTS ON THE THERMAL PERFORMANCE OF THE SOLARGENICS (LIQUID) SOLAR COLLECTOR AT OUTDOOR CONDITIONS
}

Prepared by

Wyle Laboratories

Solar Energy Systems Division

Huntsville, Alabama 35805

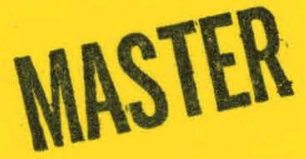

Under Subcontract with

IBM Corporation, Federal Systems Division, Huntsville, Alabama 35805

Contract NAS 8032036

National Aeronautics and Space Administration

George C. Marshall Space Flight Center, Alabama 35812

For the U. S. Department of Energy

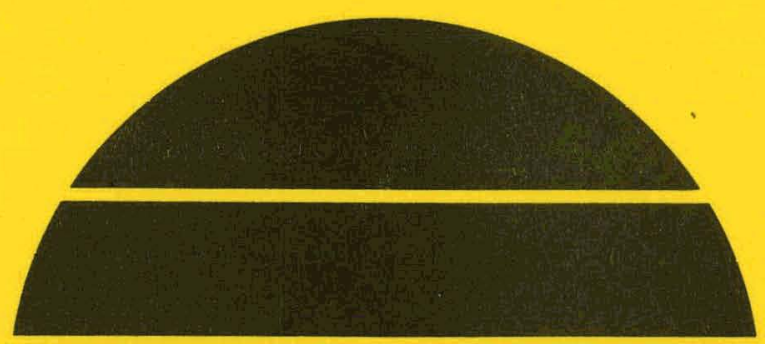

\section{U.S. Department of Energy}




\section{DISCLAIMER}

This report was prepared as an account of work sponsored by an agency of the United States Government. Neither the United States Government nor any agency Thereof, nor any of their employees, makes any warranty, express or implied, or assumes any legal liability or responsibility for the accuracy, completeness, or usefulness of any information, apparatus, product, or process disclosed, or represents that its use would not infringe privately owned rights. Reference herein to any specific commercial product, process, or service by trade name, trademark, manufacturer, or otherwise does not necessarily constitute or imply its endorsement, recommendation, or favoring by the United States Government or any agency thereof. The views and opinions of authors expressed herein do not necessarily state or reflect those of the United States Government or any agency thereof. 


\section{DISCLAIMER}

Portions of this document may be illegible in electronic image products. Images are produced from the best available original document. 
Th1s report was prepared to document work sponsored by the United States Goverament. NeIther the United States nor 1ts agents the United States Department of Energy, the United States Nat1onal Aeronautics and Space Adminfstration, nor any federal employees, nor any of their contractors, subcontractors or the1r employees, make any werranty, express or 1 mplled, or ssaume any legal liab1l1ty or responstb1lity for the accuracy, completeness, or usefulness of any informat1on, apparatus, product or process disclosed, or represent that its use would not infinge privately owned rights. 


\begin{tabular}{|c|c|}
\hline $\begin{array}{l}\text { 1. REPORT NO. } \\
\text { DOE/ NASA CR-150523 }\end{array}$ & 3. RECIPIENT'S CATALOG NO. \\
\hline \multirow{2}{*}{$\begin{array}{l}\text { 4. TITLE AND SUBTITLE } \\
\text { Long-Term Weathering Effects on the Thermal Performance of } \\
\text { the Solargenics (Liquid) Solar Collector at Outdoor Conditions }\end{array}$} & $\begin{array}{l}\text { 5. REPORT DATE } \\
\text { July } 1979\end{array}$ \\
\hline & 6. PERFORMING ORGANIZATION CCIDE \\
\hline 7. AUTHOR(S) & $\begin{array}{l}\text { 8. PERFORMING ORGANIZATION REPOR I. } \\
\text { Adden. to Wyle TR-531-28 }\end{array}$ \\
\hline \multirow{3}{*}{$\begin{array}{l}\text { 9. PERFORMING ORGANIZATION NAME AND ADDRESS } \\
\text { Wyle Laboratories } \\
\text { Solar Energy Systems Division } \\
\text { Huntsville, Alabama } 35805\end{array}$} & 10. WORK UNIT NO. \\
\hline & $\begin{array}{l}\text { 11. CONTRACT OR GRANT NO. } \\
\text { NAS } 8-32036\end{array}$ \\
\hline & 13. TYPE OF REPOR $\because$ \& PERIOD COVERED \\
\hline \multirow{2}{*}{$\begin{array}{l}\text { 12. SPONSORING AGENCY NAME AND ADDRESS } \\
\text { National Aeronautics and Space Administration } \\
\text { Washington, D. C. } 20546\end{array}$} & Contractor Report \\
\hline & 1.4. SPONSORING AGENCY CODE \\
\hline
\end{tabular}

This work was done under the technical management of Mr. Charles N. Thomas, George C. Marshall Space Flight Center, Alabama.

18. ABSTRACT

This report presents the test procedures used and the results obtained during the evaluation test program of the Solargenics single-covered liquid solar collector. The tests were performed under outdoor natural conditions at the Solar Test Facility at MSFC, following longterm exposure to natural weathering conditions. The collector was under stagnation conditions from August 26, 1978, to June 13, 1979, for a total of approximately ten months.

The Solargenics solar collector is manufactured by Solargenics, 808 Gretna Green Way, Los Angeles, California. The solar collector is a liquid, single-glazed, flat-plate collector, and is about 240 inches long, 38 inches wide, and 3.8 inches in depth.

For further information on the Solargenics test procedures and performance evaluation, see DOE/NASA CR-150857.

\begin{tabular}{|c|c|c|c|}
\hline 17. KEY WORDS & & $\begin{array}{l}\text { 18. DISTRIBUTION STATEMENT } \\
\text { Unclassified-Unlimited } \\
\text { WILLIAM A. BROOKSBANK, fR } \\
\text { Mgr, Solar Energy Applications }\end{array}$ & UC-59c \\
\hline $\begin{array}{l}\text { 19. SECURITY CLASSIF. (of thlo soport) } \\
\text { Unclasssified }\end{array}$ & $\begin{array}{r}\text { 20. SECURITY CLAS } \\
\text { Unclassifie }\end{array}$ & \begin{tabular}{|l|c|} 
SIf. (ol thle pago) & 21. NO. OF PAGES \\
12
\end{tabular} & $\begin{array}{l}\text { 22. PRICE } \\
\text { NTIS }\end{array}$ \\
\hline
\end{tabular}


THIS PAGE

\section{WAS INTENTIONALLY LEFT BLANK}


4.0

SUMMARY

TEST REQUIREMENTS AND PROCEDURES 3

5.0

5.1 Collector Thermal Efficiency Test

TABLE I

TABLE II

Figure 1
SOLARGENICS LIQUID COLLECTOR PERFORMANCE RECHECK AFTER LONG TERM EXPOSURE TO NATURAL WEATHERING CONDITIONS

THERMAL PERFORMANCE TEST DATA FOR THE SOLARGENICS COLLECTOR BEFORE LONG TERM EXPOSURE

Solargenics collector Thermal Performance Test Results

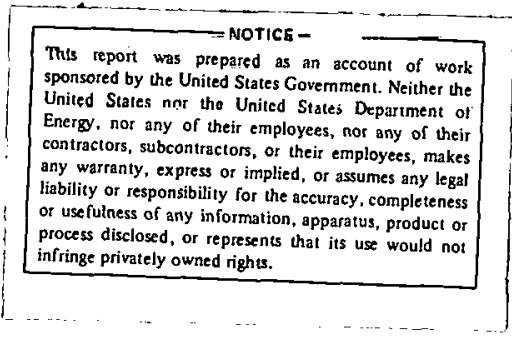

8

3




\section{$1.0 \quad$ PURPOSE}

The purpose of this report is to present the test procedures used and the test results obtained during an evaluation test program. The test program was conducted to obtain thermal performance data on a solargenics single-covered liquid solar collector under outdoor conditions (Reference 2.1), following long term exposure to natural weathering conditions. The tests were conducted utilizing the Marshall space Flight Center Breadboard Test Facility in accordance with the outdoor test requirements of Reference 2.2.

\section{$2.0 . \quad$ REFERENCES}

$2: 1 \quad \mathrm{CR}-150857$

2.2

ASHRAE $93-77$

Thermal Performance Evaluation of the Solargenics Solar collector at Outdoor conditions

Method of Testing to Determine the Thermal Performance of Solar Collectors

\subsection{COLLECTOR DESCRIPTION}

Manufacturer:

Manufacturer's Address:

Model Number:

Serial Number:

Type:

Working Fluid:

Gross Collector Area, $\mathrm{ft} \mathrm{t}^{2}$ :

Overall external dimensions:

Collector glazing:

weight, Ibs:
Solargenics

808 Gretna Green Way

Los Angeles, California

None

None

Flat Plate

$\mathrm{H}_{2} \mathrm{O}$

63.54

width, inches: 38.12

Length, inches: 240.00

Thickness, inches: $3-7 / 8$

Aperture area, $\quad 53.34 \mathrm{ft}^{2}$ It $\mathrm{L}^{2}$ :

Single

(Not available) 
Thermal performance tests were conducted on the Solargenics single-covered liquid solar collector following long term exposure to natural weathering conditions. The collector was mounted on the weathering test stand at the Solar Test Facility at Marshall space Flight Center, Alabama, with exposure to the natural ambient environment.. The collector was under stagnation conditions from August 26, 1978, to June 13, 1979. The collector was retested at the MSFC Breadboard Test Facility under outdoor natural conditions on June 22, 1979: The total weathering period was approximately ten months.

Visual inspection of the collector," prior to retest, indicated that some rain water leakage had occurred at the cover seals leaving water marks on the absorber plate. No other material deficienciee were apparent. The test results indicated that a small change in performance had occurred. A slight increase in the negative slope indicates an increase in the heat loss parameters. The slightly lower intercept on the ordinate axis is likely a result of a slight decrease in the absorptivity of the absorber plate or a decrease in the transmissivity of the cover glass. 
Thermal performance evaluation criteria shall correspond to that of reference 2.1. Data shall be obtained at inlet temperatures of $0,25,50$ and $100^{\circ} \mathrm{F}$ above the ambient temperature at the liquid flow rate of $1.50 \mathrm{GPM}$. The test shall be conducted at times having weather conditions such that the integrated average insolation measured in the plane of the collector used for computation of instantaneous efficiency values shall not be less than $200 \mathrm{BTU} / \mathrm{Hr} \cdot \mathrm{Ft}^{2}$. The air velocity across the collector surface shall be measured and recorded as part of the test data. The following data shall be recorded during the test at each test condition.

1. Ambient temperature.

2. Collector inlet liquid temperature.

3. Collector outlet liquid temperature.

4. Collector differential temperature.

5. Total solar flux.

6. Flow rate.

7. Wind speed and direction.

Test Procedure

1. Mount test specimen and its associated equipment on test bed \#2 at a tilt angle of $45^{\circ}$.

2. Assure data acquisition system is operational.

3. Establish the proper flowrate and. inlet temperature for each test designation.

4. Continuously adjust the inlet temperature and flow rate to maintain the deeirod "data point" characteristics, as specified in paragraph 4.1 .

5. After steady state conditions have been obtained for each "data point," record data for a minimum of five minutes. Monitor the test parameters by using the data acquisition system at the test site.

6. Once steady state data has been obtained for all specified data points, label and save the printout from teletype as a record. 
6.0

ANALYSIS

6.1 Thermal Performance Test

The analysis of data contained in this report is in accordance with the National Bureau of Standards recommended approach. This approach is outlined below.

The efficiency of a collector is stated as:

$$
\eta=\frac{q_{u} / A}{I}=\frac{\dot{m} C_{t f}\left(t_{f, e}-t_{f, i}\right)}{I}
$$

where:

$$
\begin{aligned}
& \mathrm{q}_{\mathrm{u}}=\text { Rate of useful energy extracted from the } \\
& \text { solar collector (BTU/Hr) } \\
& A=\text { Gross collector area }\left(F t^{2}\right) \\
& \text { I = Total solar energy incident upon the plane. }
\end{aligned}
$$

Rewriting Equation (1) in terms of the total collector area yield:

$$
n=\frac{(\dot{m} A) c_{t f}\left(t_{f, e}-t_{f, i}\right)}{(I A)}=\frac{\dot{M} c_{t f}\left(t_{f, e}-t_{f, i}\right)}{P_{i}}
$$

Notice that:

$\mathrm{P}_{\mathrm{i}}=\mathrm{IA}=$ Total power incident on the collector.

$\dot{\mathrm{m}} \dot{\mathrm{A}}=\dot{\mathrm{M}}=$ Total mass flow rate through the collector.

Therefore $\dot{M} c_{t f}\left(t_{f, e}-t_{f, i}\right)=$ Total power collected by the collector. 
Substitution in Equation (2) results in:

$n=$ Pabs

where:

Pabs = Total collected power

Pinc $=$ Total incident power

This value of efficiency is expressed as a percentage by multiplying by 100. This expression for percent efficiency is:

Collector Efficiency $=\frac{\text { Pabs }}{\text { Pinc }} \times 100$

or from Equation (2), collector efficiency is defined

by the equation:

$\&$ Eff $=\frac{\dot{M} c_{t f}\left(t_{f, e}-t_{f, i}\right)}{\text { Pinc }} \times 100$

Each term in Equation (5) was measured and recorded inbependently during the test.

The mean value of efficiency was determined over a fiveminute period during which the test conditions remained in a quasi-steady state. Each five-minute period constitutes one "data point" as is graphically depicted on a plot uf percont efficiency versus

$$
\left.\left(t_{i}-t_{a}\right) / I\right)
$$

where:

$t_{i}=$ Liquid inlet temperature $\left({ }^{\circ} \mathrm{F}\right)$

$t_{a}=$ Ambient temperature $\left({ }^{\circ} \mathrm{F}\right)$

$I$. = Incident flux per unit area (BTU/Hr $\cdot \mathrm{r}^{2}{ }^{2}$ )

The abscissa term $\left(\left(t_{i}-t_{a}\right) / I\right)$ was used to normalize the effect of operating at different values of $I, t_{i}$ and ta. The results are shown graphically in Figure 1 with the supporting test data given in Table $I$. 
6.0

ANALYSIS AND RESULTS (Continued)

6.1

Thermal Performance Test (Continued)

Reference 2.2 uses the following terms relating to the thermal efficiency graph:

$\mathrm{F}_{\mathrm{R}} \propto \tau=$ intercept of the efficiency curve on the ordinate axis

$F_{\mathrm{R}_{\mathrm{L}}}$ = the negative of the slope of the efficiency curve

$F_{\mathrm{R}} \quad=$ the solar heat removal factor

$\alpha \tau=$ absorptance of the collector surface for solar radiation

$\tau=$ transmittance of the solar collector cover plate

$\mathrm{U}_{\mathrm{L}} \quad=$ solar collector heat transfer loss coefficient

A comparison of the before and after weathering efficiency curves indicates that the slope, $F_{R} U_{L}$, did change slightly and that the value of $F_{R} d \tau$ did drop a marginal amount. 
TABLE I

SOLARGENICS IIQUID COLLECTOR PERFORMANCE RECHECK AFTER LONG TERM EXPOSURE TO NATURAL WEATHERING CONDITIONS

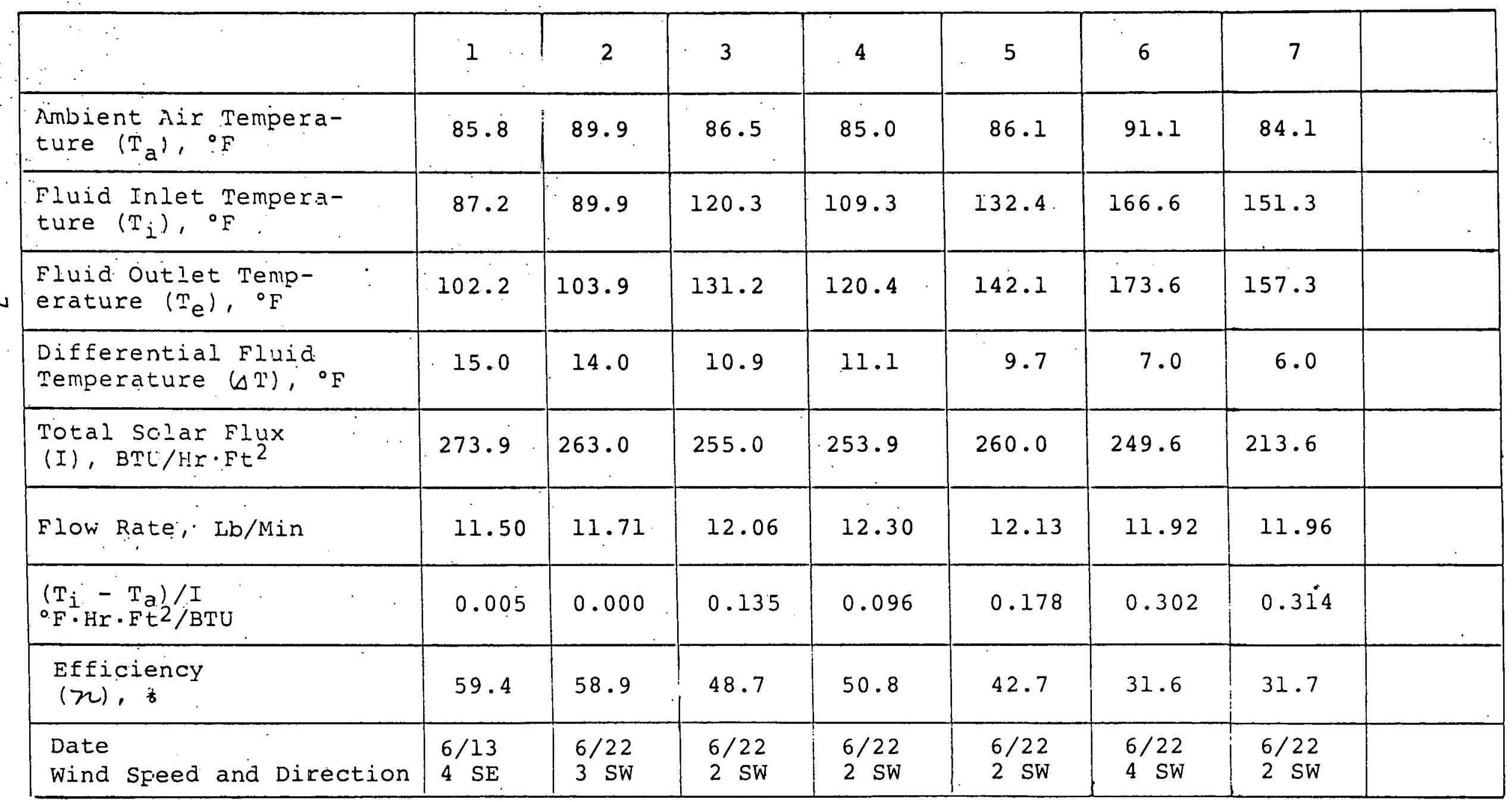




\section{TABLE II}

THERMA- PERFORMANCE TEST DATA FOR THE SOLARGENICS COLLECTOR BEFORE IONG TERM EXPOSURE

Page 1 of 2

\begin{tabular}{|c|c|c|c|c|c|c|c|c|}
\hline $\begin{array}{l}\text { Date } \\
\text { Wind Speed and Direction }\end{array}$ & $\begin{array}{r}7 / 18 \\
5 \Xi\end{array}$ & $\begin{array}{l}7 / 18 \\
5 W\end{array}$ & $\frac{7 / 20}{5 E}$ & $\begin{array}{l}7 / 20 \\
5 W\end{array}$ & $7 / 24$ & $\frac{7 / 24}{5 W}$ & $\begin{array}{c}7 / 24 \\
7 \mathrm{E}\end{array}$ & $7 / 24$ \\
\hline $\begin{array}{l}\text { Ambient Air Tempera- } \\
\text { ture }\left(\mathrm{T}_{\mathrm{a}}\right),{ }^{\circ} \mathrm{F}\end{array}$ & 89.5 & 90.0 & 92.0 & 92.5 & 92.0 & 91.9 & 91.3 & 91.6 \\
\hline $\begin{array}{l}\text { Fluid Inlet Tempera- } \\
\text { ture }\left(T_{i}\right), \circ \mathrm{F} .\end{array}$ & 91.8 & 92.0 & 91.7 & 91.9 & 115.1 & 115.2 & 115.4 & 115.5 \\
\hline $\begin{array}{l}\text { Fluid outlet Temp- } \\
\text { erature }\left(\mathrm{T}_{e}\right), \stackrel{\mathrm{O}}{\mathrm{F}}\end{array}$ & 106.2 & 106.2 & 105.4 & 105.9 & 129.7 & 129.6 & 129.9 & 129.6 \\
\hline $\begin{array}{l}\text { Differential Fluid } \\
\text { Temperature }(\Delta \mathrm{T}),{ }^{\circ} \mathrm{F}\end{array}$ & 14.4 & 14.2 & 13.7 & 14.0 & 14.6 & 14.4 & 14.5 & 14.1 \\
\hline $\begin{array}{l}\text { Total Solar Flux } \\
(I) ; \mathrm{BTU} / \mathrm{Hr} \cdot \mathrm{Ft}^{2}\end{array}$ & 303.6 & 310.3 & 282.6 & $28: 3.0$ & 320.6 & 314.9 & 316.4 & 314.1 \\
\hline Flow Rate, GPM & 1.58 & 1.58 & 1.54 & 1.54 & 1.54 & 1.54 & 1.55 & 1.55 \\
\hline $\begin{array}{l}\left(T_{j}-T_{a}\right) / I \\
{ }^{\circ} F \cdot H r \cdot F t^{2} / B T U\end{array}$ & .01 & .01 & .00 & .00 & .07 & .07 & .08 & .08 \\
\hline $\begin{array}{l}\text { Efficiency } \\
(\boldsymbol{n}), \text { is }\end{array}$ & 58.7 & 56.6 & 58.4 & 59.6 & 54.6 & 54.8 & 55.2 & 54.1 \\
\hline Specific Gravity & 0.996 & 0.996 & 0.996 & 0.996 & 0.989 & 0.989 & 0.989 & 0.989 \\
\hline
\end{tabular}


TABLE II (Continued)

Page 2 of 2

\begin{tabular}{|c|c|c|c|c|c|c|c|c|}
\hline $\begin{array}{l}\text { Date } \\
\text { Wind Speed and Direction }\end{array}$ & 10W & $8 W$ & $6 / 24$ & $8 / 24$ & $7 / 18$ & $7 / 18$ 3E & $7 / 18 \quad 8 w$ & $7 / 18$ 10W \\
\hline $\begin{array}{l}\text { Ambient Air Tempera- } \\
\text { ture }\left(T_{a}\right),{ }^{\circ}\end{array}$ & 93.5 & 93.0 & 92.5 & 92.3 & 93.9 & 93.9 & .94 .5 & 95.2 \\
\hline $\begin{array}{l}\text { Fluid Inlet Tempera- } \\
\text { ture }\left(T_{i}\right),{ }^{\circ} \mathrm{F} .\end{array}$ & 145.4 & 145.4 & 145.3 & 145.1 & 187.8 & 189.4 & 189.9 & 189.9 \\
\hline $\begin{array}{l}\text { Fluid Outlet Temp- } \\
\text { erature }\left(\mathrm{T}_{\mathrm{e}}\right),{ }^{\circ} \mathrm{F}\end{array}$ & 158.3 & 158.2 & 158.6 & 158.4 & 195.4 & 197.5 & 199.4 & 199.4 \\
\hline $\begin{array}{l}\text { Differential Fluid } \\
\text { Temperature }\left(\Delta \mathrm{I}^{\prime}\right),{ }^{\circ} \mathrm{F}\end{array}$ & 12.9 & 12.8 & 13.3 & 13.3 & 7.6 & 8.1 & 9.5 & 9.5 \\
\hline $\begin{array}{l}\text { Total solar Flux } \\
(I), \mathrm{BIU} / \mathrm{HI} \cdot \mathrm{Ft} \mathrm{L}^{2}\end{array}$ & 322.4 & 324.6 & 323.4 & 331.4 & 300.4 & 302.4 & 315.8 & 308.0 \\
\hline Flow Rate, GPM & 1.51 & 1.51 & 1.51 & 1.51 & 1.57 & 1.57 & 1.57 & 1.57 \\
\hline $\begin{array}{l}\left(T_{i}-T_{a}\right) / I \\
{ }^{\circ} F \cdot H r \cdot F t^{2} / B T U\end{array}$ & .16 & .16 & .16 & .16 & .31 & .32 & .30 & .31 \\
\hline $\begin{array}{l}\text { Efficiency } \\
(\varkappa), \frac{8}{8}\end{array}$ & 46.3 & 46.1 & 48.0 & 46.9 & 30.2 & 31.9 & 35.9 & 36.8 \\
\hline Specific Gravity & .984 & .984 & .984 & .984 & .966 & .966 & .966 & .966 \\
\hline
\end{tabular}




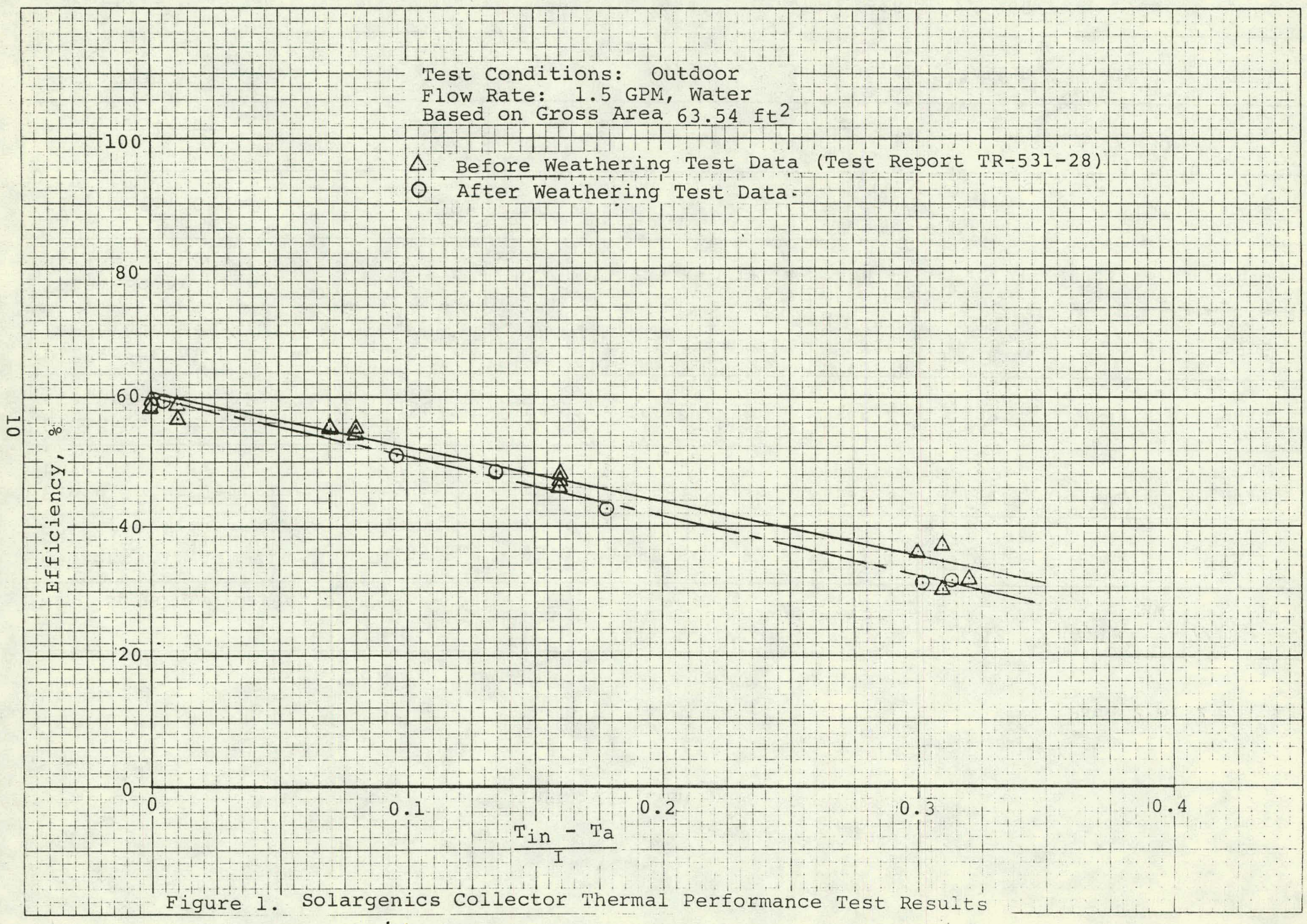

Figure 1. Solargenics Collector Thermal Performance Test Resuits 